\title{
ARTICLES
}

\section{Why fishing magnifies fluctuations in fish abundance}

\author{
Christian N. K. Anderson ${ }^{1}$, Chih-hao Hsieh ${ }^{1,2,3,4}$, Stuart A. Sandin ${ }^{1}$, Roger Hewitt ${ }^{5}$, Anne Hollowed ${ }^{6}$, \\ John Beddington ${ }^{7}$, Robert M. May ${ }^{8} \&$ George Sugihara ${ }^{1}$
}

It is now clear that fished populations can fluctuate more than unharvested stocks. However, it is not clear why. Here we distinguish among three major competing mechanisms for this phenomenon, by using the 50 -year California Cooperative Oceanic Fisheries Investigations (CalCOFI) larval fish record. First, variable fishing pressure directly increases variability in exploited populations. Second, commercial fishing can decrease the average body size and age of a stock, causing the truncated population to track environmental fluctuations directly. Third, age-truncated or juvenescent populations have increasingly unstable population dynamics because of changing demographic parameters such as intrinsic growth rates. We find no evidence for the first hypothesis, limited evidence for the second and strong evidence for the third. Therefore, in California Current fisheries, increased temporal variability in the population does not arise from variable exploitation, nor does it reflect direct environmental tracking. More fundamentally, it arises from increased instability in dynamics. This finding has implications for resource management as an empirical example of how selective harvesting can alter the basic dynamics of exploited populations, and lead to unstable booms and busts that can precede systematic declines in stock levels.

Ecologists have long suspected that harvesting a species has the unintended consequence of destabilizing the abundance of that species ${ }^{1,2}$. This would be undesirable, because boom-and-bust cycles can increase the likelihood of local extinctions ${ }^{3}$ and can harm the economic market for the species. However, this connection has been remarkably difficult to prove. A historic example is the collapse of the California sardine fishery in the late 1940s, which some argued was caused primarily by fishing ${ }^{4,5}$, but which others attributed to cooling sea surface temperatures or to shifting wind patterns ${ }^{6-8}$. Because landings records contain no information about unexploited species, there is no control group to disentangle environmental effects from fishing effects. Partly to address this conundrum, CalCOFI was initiated to collect data both on fished and unfished species living in the same environment. CalCOFI overcame the reliance on landings data by sampling the ichthyoplankton assemblage, a well-known proxy for current adult (spawning) biomass ${ }^{9-11}$. Fifty years into the study, Hsieh et al. ${ }^{9}$ used the CalCOFI ichthyoplankton database $^{12}$ to separate the effects of fishing from other variables, and demonstrated that fishing significantly increases temporal variability of populations in the southern sector of the California Current ecosystem (Fig. 1). Increased variability is thought to be related to the truncated age/size structure ${ }^{3,4,9,13-17}$ of commercially fished species, a phenomenon caused by selective removals of larger, older individuals that previously provided stability to the population.

Here we examine three competing hypotheses for the link between fishing and stock variability ${ }^{1,2,9,16,18}$. First, fishing itself can vary year to year and this can translate directly into increased population variability $^{19}$. Second, fished populations that become dominated by relatively small-bodied and young individuals are less able to smooth out environmental fluctuations, and are thus more likely than unfished stocks to track directly those fluctuations ${ }^{4,9,13}$. Finally, fished populations that become dominated by small-bodied and young individuals are more prone to exhibit unstable dynamics due to changing demographic parameters ${ }^{20,21}$. These are not mutually

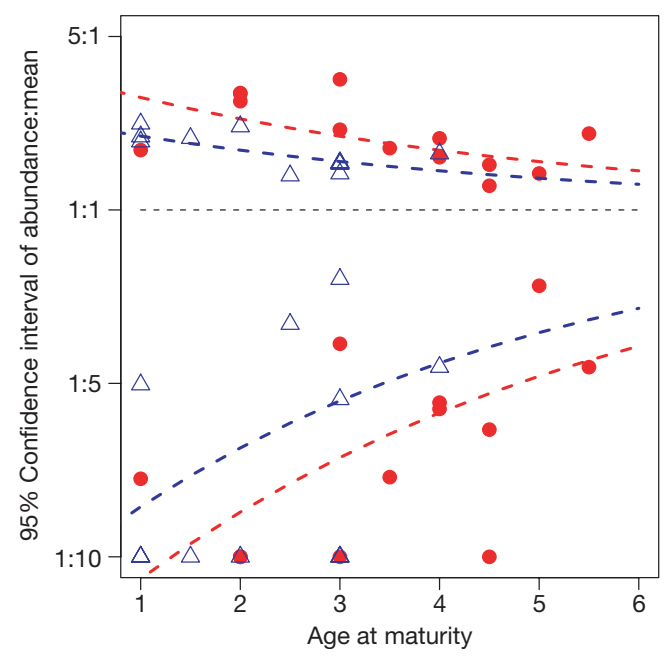

Figure 1 | In addition to an increased coefficient of variation ${ }^{9}$, exploited species (red dots) exhibit larger booms and busts than unexploited species (blue triangles) of a similar age. The 95 th and the 5 th percentiles of abundance are shown for each species, with exponential fits (dashed lines) for the exploited and unexploited species. Note that for all species, the busts (lower range) are more pronounced than the booms $(P<0.0001)$.

Populations less than one-tenth mean size probably fell below detection levels and were conservatively fixed at one-tenth mean size; thus, the effect may be more pronounced than depicted here.

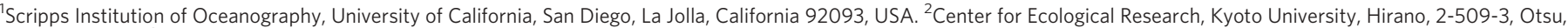

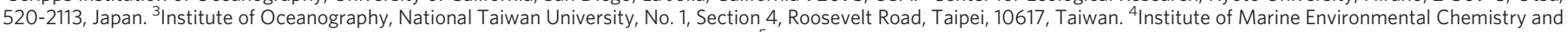

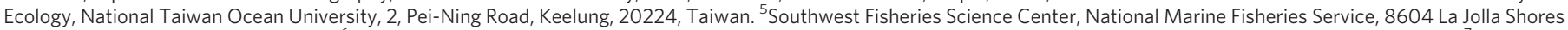

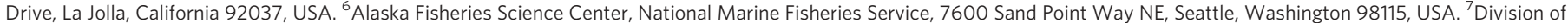

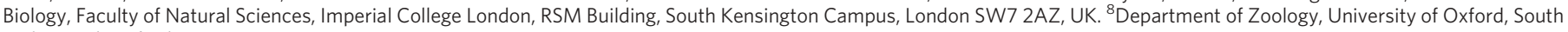
Parks Road, Oxford OX1 3PS, UK. 
exclusive hypotheses; all three could act together to increase variability. Here we analyse the relative importance of each hypothesis as a cause of the increase in population variability of fished stocks observed in the southern California Current ecosystem.

\section{Hypothesis 1 (variable fishing)}

According to hypothesis 1, a fish stock is expected to vary more if exploited heavily some years and lightly in others. Jonzén et al. ${ }^{22}$ discovered a positive correlation between the variance in fishing mortality and the variance in the standing stock biomass of Baltic cod populations. We use their method on the CalCOFI database, to test this hypothesis for the seven exploited species whose fishing mortality is available from National Marine Fisheries Service stock assessment reports (Supplementary Table 1) and find no evidence that variability in fishing mortality is associated with variability in either larval density (Fig. 2) or estimated spawning biomass (Supplementary Fig. 2). Therefore, although it is reasonable to expect the variability of these populations to be somewhat influenced by year-to-year differences in fishing effort, hypothesis 1 alone does not explain the observed increase in variability of these data.

\section{Hypotheses 2 and 3 (age-truncation effects)}

The other two hypotheses are closely related. Because fishing typically targets the larger individuals of a species, the average size- and thus age-of target populations is often found to decrease ${ }^{14-16,18,23}$. Age truncation leading to increased population variability has been documented in several populations', and is here referred to as the 'age truncation effect' (ATE) ${ }^{13}$. Such juvenescence can affect population variance in two separable ways.

Hypothesis 2 suggests that when new recruits compose most of the stock, the juvenescent population is more likely to track variable environmental processes directly ${ }^{4,5}$. Although younger and smaller fish are more susceptible to changes in the environment, older and larger fish tend to integrate over environmental fluctuations and survive hard times better through 'bet-hedging' strategies ${ }^{18,24-27}$ including fat storage, the ability to migrate and avoid poor areas, having flexibility in spawning times and locations, and production of high-quality offspring that survive in a broader suite of environmental conditions ${ }^{18}$. Bet-hedging strategies are well documented in

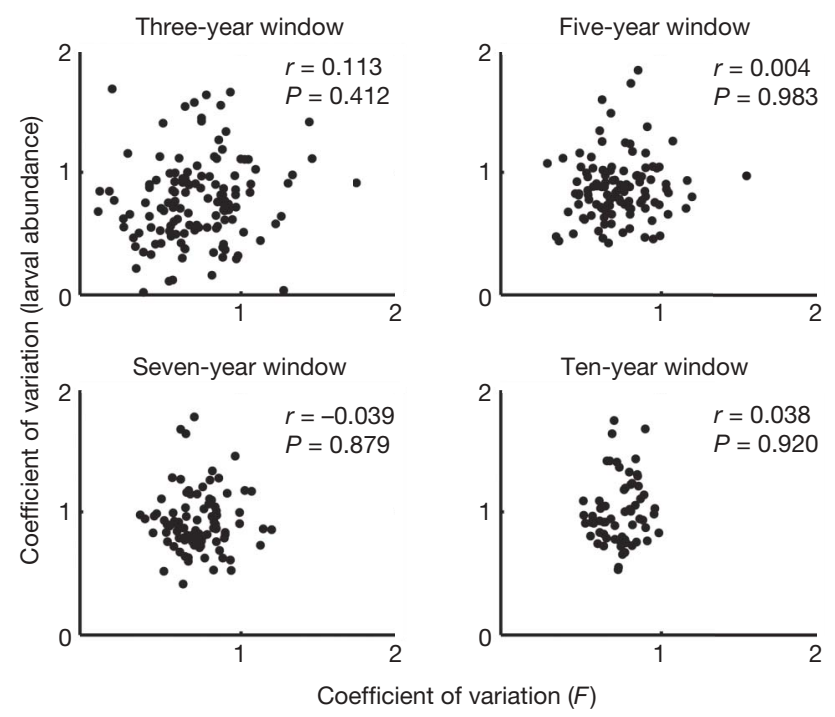

Figure 2 | Hypothesis 1: does variable fishing cause variability in fish stocks? There is no positive relation between the variability in the coefficient of variation of fishing mortality $(F)$ and population variability coefficient of variation (larval abundance) using a three-, five-, seven-, and ten-year moving window. Thus variability in fishing mortality (removing more fish some years than others) does not account for variability in fished stocks in the CalCOFI domain. association with long-tailed age distributions ${ }^{18,24-27}$. Loss of hedging capacity through age truncation should produce a time-series signal that more closely exhibits the linear (statistically noisy) characteristics found in physical oceanographic data for that region ${ }^{21}$.

By contrast, under hypothesis 3, the increased variability of exploited fish stocks comes from changes in demographic parameters that amplify nonlinear behaviour ${ }^{20,21}$. There are many ways that the ATE can change demographic parameters, for example by increasing intrinsic population growth rates or by increasing nonlinear coupling of demographic parameters to environmental noise ${ }^{20,28}$. The resulting population dynamics will produce a more variable time series with more nonlinear behaviour than seen in unexploited fish stocks.

\section{Separating environment and demography}

Because hypothesis 2 implies increased tracking of linear environmental variation, whereas hypothesis 3 describes an enhanced nonlinear response, we can distinguish these subtle alternatives by comparing the nonlinearity in the time series of exploited species relative to unexploited species. Here, nonlinearity is quantified using S-maps ${ }^{29}$, a model validation criterion that uses out-of-sample predictions from equivalent linear versus nonlinear models to identify the dynamics behind time-series observations. The model either weights all data equally $(\theta=0)$ to make linear forecasts, or gives more weight to data points with similar recent histories $(\theta>0)$, a hallmark of nonlinear behaviour ${ }^{29,30}$. The nonlinearity of a time series is determined by how much the correlation $(\rho)$ between forecasts and observations increases as models are tuned towards nonlinear solutions; that is, how much forecast skill increases $(\Delta \rho)$ when $\theta>0$ $\left(\Delta \rho=\rho_{\theta>0}-\rho_{\theta=0}\right.$; see Methods).

When CalCOFI ichthyoplankton time series are modelled using linear autoregression ( $\mathrm{S}$-maps with $\theta=0$ ), fished species are slightly more predictable than unfished species $(\rho=0.514$ and 0.504 , respectively; Fisher's test $P=0.64$; Supplementary Fig. 3). However, this possible evidence for hypothesis 2 is marginal (Supplementary Table 2). Indeed, nonlinear models describe the CalCOFI ichthyoplankton time series better $(\theta=0.3$ for both), and more importantly, fished species exhibit significantly more nonlinearity than the unfished group (Fig. 3a; unfished $\Delta \rho=0.037, P=0.25$; fished $\Delta \rho=0.083, P<0.01$; Fisher's test, $P<0.003)$. If the increase in variance is due to vulnerable, young fish simply tracking the linear environment more closely, then the nonlinearity $(\Delta \rho)$ of fished species should decrease. This prediction is contradicted by the data.
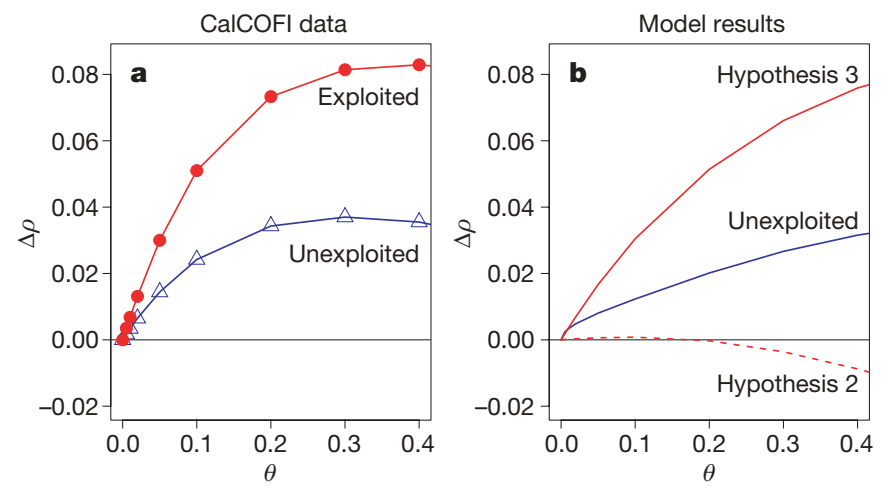

Figure 3 | Discriminating between hypotheses 2 and 3. A larger $\Delta \rho$ as $\theta$ is tuned from linear $(\theta=0)$ towards nonlinear solutions $(\theta>0)$ indicates a stronger nonlinear signal $\left(\Delta \rho=\rho_{\theta>0}-\rho_{\theta=0}\right)$. a, S-map analysis shows that fished populations (red) are significantly more nonlinear than unexploited populations (blue) $(P=0.0027)$, supporting hypothesis 3 (demographic change), not hypothesis 2 (tracking), as the agent behind amplified variability with fishing. b, Corroborative model results. Equation (1) was fitted to data for unexploited species (blue line). Increased environmental sensitivity makes time series appear more linear (dashed red line). However, increasing growth rate $r$ produces an enhanced nonlinear signature (solid red line) as observed for exploited species in a. 
Rather, fishing pressure has enhanced the nonlinear behaviour of the fished populations. Therefore, the data suggest that altered dynamics resulting from a truncated age structure overwhelm the propensity of young fish to track the environment passively and that dynamic instability is the agent behind the observed increase in variance. Increased nonlinearity has explained higher variance in other contexts ${ }^{29,31}$.

\section{Identifying sources of nonlinearity}

We illustrate the distinction between hypotheses 2 and 3 with a population growth model having the familiar Ricker-form ${ }^{29,32}$

$$
N_{t+1}=N_{t} \exp \left[r\left(1-N_{t}\right)\right]+c \varepsilon
$$

where $N$ is population size (in units of number or biomass), $r$ is the intrinsic population growth rate, $\varepsilon$ is environmental variability with unit standard deviation, and $c$ is environmental susceptibility (see Methods, Supplementary Fig. 4 and Supplementary Discussion). Hypothesis 2 corresponds to an increase in environmental susceptibility $c$; hypothesis 3 corresponds to alteration of a demographic parameter: for this example we increase $r$. Forecast skill does not improve with nonlinear tuning $(\theta>0)$ as environmental noise $(c \varepsilon)$ is increased, but declines with $\theta$, as would be expected if the time series were dominated by linear statistical effects (Fig. 3b, dashed line; see Methods). We find this result is maintained whether $\varepsilon$ is 'white' noise, autocorrelated 'red' noise, $1 / f$ 'pink' noise or the actual values of the Pacific Decadal Oscillation ${ }^{33-35}$. However, under hypothesis 3 (Fig. 3b, solid red line), exploited model populations present an enhanced nonlinear signature as $r$ is increased.

At first glance, it seems counterintuitive that age truncation would increase intrinsic population growth rates (because fishing removes the largest individuals that produce the most and best quality egg $\mathrm{s}^{18,24-27}$ ); yet this trend is observed empirically in the California Current ecosystem. Because individual body size decreased and total biomass remained statistically constant ( 26 of 29 stocks $^{9}$ ), the number of young fish has increased. A larger population of shorter-lived fish requires a higher intrinsic rate of growth $(r)$; the population must produce more surviving offspring per capita per year to compensate for the shortened life span. The ultimate mechanism behind this ATE-induced increase could be competitive release and/or decreased cannibalism or possibly evolution ${ }^{23,36,37}$, leading to increased somatic growth or increased per-capita fecundity. Although other factors are probably operating, the evidence from CalCOFI points to increased growth rates as a dominant factor supporting the increase in nonlinearity observed in Fig. 3a.

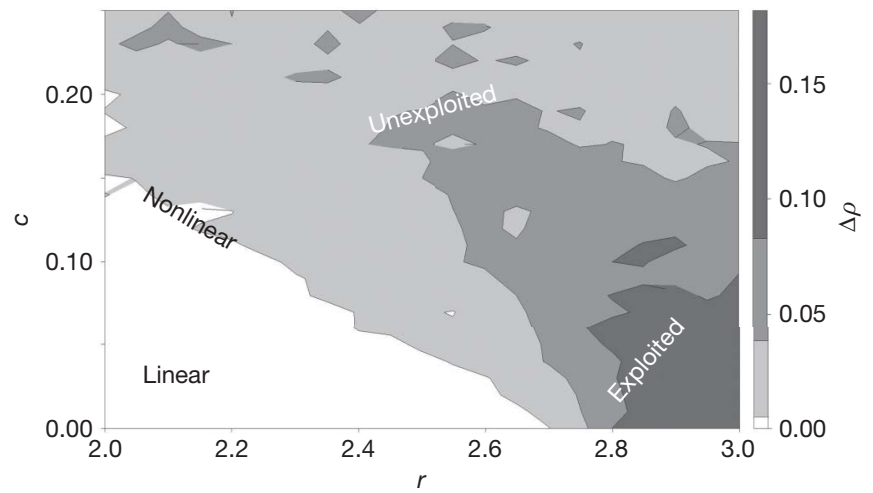

Figure 4 | Nonlinear behaviour can emerge at modest growth rates ( $r$ ) with process noise $\left(\varepsilon_{\text {process }}\right)$. Models that are underspecified (missing important components) are said to contain process noise. In this example, we evaluate the nonlinearity of $Z_{t+1}=G\left(Z_{t}+\varepsilon_{\text {process }}\right)$, where $G$ is equation (1) and $\varepsilon_{\text {process }}$ is normally distributed with mean 0 and standard deviation $c$. Process noise can amplify a nonlinear signature in the simple model for values of $r$ that would be linear alone.
Although it is well known that increasing growth rates in simple discrete growth models can lead to unstable dynamics ${ }^{38}$, values of $r$ required to evoke such behaviour in single species models are often unrealistically high. However, models with multiple species ${ }^{39}$, multiple stable states ${ }^{28}$ or models having demographic parameters that vary in complex ways with the environment ${ }^{20,21}$ produce nonlinear behaviour even at modest growth rates. More generally, process noise (error from incompletely specified models) can induce instability in otherwise stable models when the error multiplies in specific ways; that is, when an essential detail is added that has a nonlinear effect. Using the commonly studied ${ }^{29}$ form of process noise $Z_{t+1}=$ $G\left(Z_{t}+\varepsilon_{\text {process }}\right)$ where equation (1) is an example of $G$, Fig. 4 shows that generic process noise evokes nonlinear behaviour at lower growth rates. This toy representation portrays nonlinear or biologically amplified process errors.

Thus, increasing either process noise or growth rates can amplify nonlinearity. And fishing may affect both. For example, incorporating variable fishing $F_{t}$ into equation (1) so that variability in $F$ is an expression of process noise,

$$
N_{t+1}=N_{t} \exp \left[r_{i}\left(1-N_{t} / K_{t}-F_{t}\right)\right]
$$

leads to amplified nonlinearity (Fig. 5). (However, the lack of a relation in Fig. 2 eliminates this as a cause for increased variability in these data.) Similarly, modelling process errors more explicitly by adding variability directly to the demographic parameters $r$ or $K$ in equation (2) will provoke a nonlinear signature, regardless of the particular form of the noise (see Methods and Supplementary Fig. 5). It is reasonable to speculate that the baseline nonlinearity seen in the unexploited state is an expression of nonlinear process errors related to variable demographic parameters, such as those tied to ecosystem shifts and climate events for example $e^{8,9,20}$. So, although neither variability in fishing nor in the environment correlates with variability in abundance, these two sources of process error may be implicated in complex ways with the instability that accompanies fishing. Notwithstanding their potential destabilizing effects, by themselves these processes have little direct effect on the overall stock variability we observed in CalCOFI (Fig. 2, Supplementary Fig. 2, and Supplementary Tables 2 and 3).

\section{Life-history traits and nonlinearity}

Are there characteristics that make some fish stocks more susceptible to the nonlinear effects of fishing than others? To answer this question we compared the nonlinearity of exploited and unexploited stocks for various life-history traits (Table 1 and Supplementary Table 4). Table 1 identifies a qualitative tendency for the following characteristics to be associated with vulnerability to fishing: larger size at sexual maturity $(\geq 25 \mathrm{~cm})$, greater age at sexual maturity ( $\geq 3$ years), longer spawning duration ( $>7$ months), higher fecundity ( $\geq 200,000$ eggs per female per year), lower trophic level and

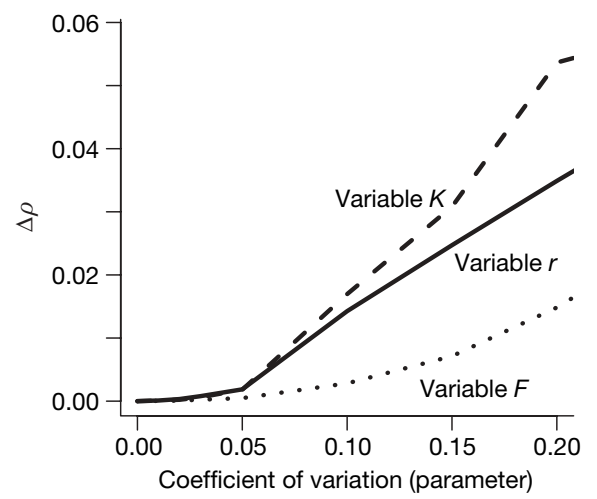

Figure 5 | Variable fishing $F$ (dotted line), growth $r$ (solid line), or carrying capacity $K$ (dashed line), can induce nonlinearity. 
Table 1 | Vulnerability of species with different life histories to destabilization by fishing

\begin{tabular}{|c|c|c|c|c|c|c|c|c|}
\hline \multirow[b]{2}{*}{ Life-history trait } & \multirow[b]{2}{*}{ Cut-off value } & \multicolumn{3}{|c|}{ Below cut-off } & \multicolumn{3}{|c|}{ Above cut-off } & \multirow[b]{2}{*}{$\begin{array}{l}\text { Difference in } \\
\text { fishing effect }\end{array}$} \\
\hline & & Unfished $\Delta \rho(n)$ & Fished $\Delta \rho(n)$ & Fishing effect & Unfished $\Delta \rho(n)$ & Fished $\Delta \rho(n)$ & Fishing effect & \\
\hline $\begin{array}{l}\text { Maximum size } \\
(\mathrm{cm})\end{array}$ & 50 & $0.062(14)$ & $0.171(3)$ & $\begin{array}{l}0.109 \\
(P=0.06)\end{array}$ & $0.067(2)$ & $0.113(10)$ & $\begin{array}{l}0.047 \\
(P<0.01)\end{array}$ & $\begin{array}{l}-0.062 \\
(P=0.19)\end{array}$ \\
\hline $\begin{array}{l}\text { Size at maturity } \\
(\mathrm{cm})\end{array}$ & 25 & $0.071(13)$ & $0.078(4)$ & $\begin{array}{l}0.007 \\
(P=0.04)\end{array}$ & $0.040(3)$ & $0.143(9)$ & $\begin{array}{l}0.103 \\
(P<0.01)\end{array}$ & $\begin{array}{l}0.096 \\
(P<0.01)\end{array}$ \\
\hline $\begin{array}{l}\text { Age at maturity } \\
\text { (years) }\end{array}$ & 3 & $0.065(9)$ & $0.055(4)$ & $\begin{array}{l}-0.010 \\
(P=0.92)\end{array}$ & $0.055(7)$ & $0.064(9)$ & $\begin{array}{l}0.009 \\
(P=0.03)\end{array}$ & $\begin{array}{l}0.019 \\
(P=0.11)\end{array}$ \\
\hline $\begin{array}{l}\text { Fecundity (eggs per } \\
\text { female per year) }\end{array}$ & 200,000 & $0.071(13)$ & $0.082(5)$ & $\begin{array}{l}0.011 \\
(P=0.03)\end{array}$ & $0.040(3)$ & $0.072(8)$ & $\begin{array}{l}0.032 \\
(P=0.03)\end{array}$ & $\begin{array}{l}0.021 \\
(P=0.21)\end{array}$ \\
\hline $\begin{array}{l}\text { Spawning duration } \\
\text { (months per year) }\end{array}$ & 7 & $0.023(6)$ & $0.093(7)$ & $\begin{array}{l}0.070 \\
(P<0.01)\end{array}$ & $0.091(10)$ & $0.205(6)$ & $\begin{array}{l}0.114 \\
(P<0.01)\end{array}$ & $\begin{array}{l}0.044 \\
(P=0.03)\end{array}$ \\
\hline Trophic level & 3.5 & $0.066(11)$ & $0.092(6)$ & $\begin{array}{l}0.026 \\
(P<0.01)\end{array}$ & $0.063(5)$ & $0.056(7)$ & $\begin{array}{l}-0.006 \\
(P=0.84)\end{array}$ & $\begin{array}{l}-0.032 \\
(P=0.04)\end{array}$ \\
\hline $\begin{array}{l}\text { Coefficient of } \\
\text { variation }\end{array}$ & 0.9 & $0.055(11)$ & $0.081(4)$ & $\begin{array}{l}0.026 \\
(P=0.02)\end{array}$ & $0.054(5)$ & $0.100(9)$ & $\begin{array}{l}0.047 \\
(P<0.01)\end{array}$ & $\begin{array}{l}0.020 \\
(P=0.11)\end{array}$ \\
\hline
\end{tabular}

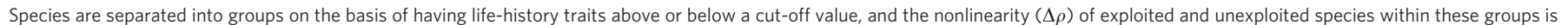

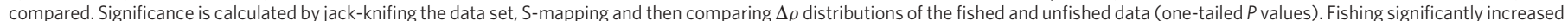

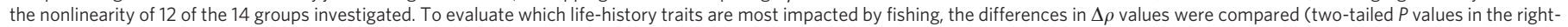
hand column). Qualitatively, susceptibility to fishing is greater in late-maturing, fecund, low-trophic-level species with year-round spawning and high variability.

more variability in abundance (coefficient of variation $\geq 0.9$ ). Thus, acknowledging the uncertainty arising from the small number of species involved in some groups, one may speculate that to a first approximation, large-maturing lower-trophic-level species that are also fecund, may be most susceptible to further destabilization by fishing, and regardless of life history the evidence suggests that increasing growth rates are driving this effect.

\section{Management implications}

In summary, fishing for big individuals without consideration of the impact on the age distribution can lead to unstable nonlinear population dynamics, and this enhanced nonlinearity helps to explain much of the volatility seen in fish stocks today (Fig. 1). Our study shows that when unconstrained, an observed demographic consequence of the ATE, that is, the effective increase of $r$, makes dramatic population change more likely-and paradoxically, in this case, can make those changes slightly more predictable in the short run. Thus target species are in double jeopardy from both fishing removals and the ATE, as stocks with higher mortality also suffer increasing fluctuations. Reduced size and age distributions have been documented in many common fisheries species, for example in Pacific salmon ${ }^{40}$, Pacific rockfish ${ }^{41}$, and North Sea ground fish ${ }^{42,43}$, suggesting the potential relevance of the ATE for many commercially important species. In terms of stock recovery, it can be premature therefore to resume fishing activities solely on the basis of recovery of biomass but before restoration of historical age distributions, even though short-term industry pressures may make this difficult to realize (for example, Atlantic swordfish ${ }^{44}$ ).

It is encouraging, however, that some managers are adopting precautionary harvest policies that protect against stock depletion and the $\mathrm{ATE}^{45,46}$. For example, in Alaska, where fishing is managed through a complex system of harvest controls, there has been relatively minor impact on the mean age of the population ${ }^{47,48}$. Nonetheless, in other areas, current policies and industry pressures that encourage lifting bans on fishing when biomass is rehabilitated, but where maximum age is not, contain risk ${ }^{18,44,49}$. Unless fishing is conducted with informed harvest controls and with market mechanisms to align incentives and manage financial risks associated with volatile supplies, we can expect a future of instability in fish populations and suboptimal performance of the industries built on them.

\section{METHODS SUMMARY}

Hypothesis 1 was tested by examining the relation between the coefficient of variation in fishing mortality and the coefficient of variation of spawning biomass (larval indicators and fishery-based estimates) for Southern Region California Current fisheries (Fig. 2 and Supplementary Fig. 2). Variability was calculated for windows $3-10$ years long.
Hypotheses 2 and 3 were tested with S-maps on composite CalCOFI ichthyoplankton time series, using methods described in detail elsewhere ${ }^{21,50}$. Briefly, larval time series were composited end-to-end, and nonlinearity of fished versus unfished species was assessed by computing $\Delta \rho$ with an embedding dimension $E=3$ (Supplementary Materials).

Hypotheses 2 and 3 are illustrated with a simple model (equation (1)) whose behaviour is generic to a large class of fisheries models (Supplementary Discussion). First, a baseline is established by fitting parameters to the observed variance (Supplementary Fig. 6) and nonlinearity of unexploited CalCOFI populations (Fig. 3b, blue line). Next, to model hypothesis 2, environmental susceptibility $(c)$ is increased to simulate direct environmental tracking with the ATE (Fig. 3b, dashed line). Alternative types of environmental noise were simulated for hypothesis 2 (red, $1 / f$, white, low-pass filtered and the actual Pacific Decadal Oscillation values ${ }^{33-35}$ ), and did not affect the qualitative outcome. Finally, hypothesis 3 is here simulated by increasing species-specific growth rates ( $r$ ) (Fig. 3b, solid red line). Various forms of process noise were also simulated. All standard statistical analyses were performed with $\mathrm{R}$ software version 2.3.0.

\section{Received 12 November 2007; accepted 22 February 2008.}

1. Beddington, J. R. \& May, R. M. Harvesting natural populations in a randomly fluctuating environment. Science 197, 463-465 (1977).

2. May, R. M., Beddington, J. R., Horwood, J. W. \& Shepherd, J. G. Exploiting natural populations in an uncertain world. Math. Biosci. 42, 219-252 (1978).

3. Lande, R., Engen, S. \& Saether, B. Stochastic Population Dynamics in Ecology and Conservation (Oxford Univ. Press, New York, 2003).

4. Murphy, G. I. Vital statistics of the Pacific sardine (Sardinops caerulea) and the population consequences. Ecology 48, 731-736 (1967).

5. Murphy, G. I. Population biology of the Pacific sardine (Sardine caerulea). Proc. Calif. Acad. Sci. 4th ser. 34, 1-84 (1966).

6. Marr, J. C. in Proc. World Sci. Meeting Biol. Sardines Related Species (eds Rosa, H. \& Murphy, G.) 667-791 (FAO, Rome, 1960).

7. Clark, F. N. \& Marr, J. C. Population dynamics of the Pacific sardine. CalCOFI Prog. Rep. 4, 11-48 (1955).

8. Rykaczewski, R. R. \& Checkley, D. M. Jr. Influence of ocean winds on the pelagic ecosystem in upwelling regions. Proc. Natl Acad. Sci. USA 105, 1965-1970 (2008).

9. Hsieh, C. H. et al. Fishing elevates variability in the abundance of exploited species. Nature 443, 859-862 (2006).

10. Hunter, J. R. \& Lo, N. C. H. Ichthyoplankton methods for estimating fish biomass introduction and terminology. Bull. Mar. Sci. 53, 723-727 (1993).

11. Gunderson, D. R. Surveys of Fisheries Resources (John Wiley, New York, 1993).

12. Hsieh, C. H. et al. A comparison of long-term trends and variability in populations of larvae of exploited and unexploited fishes in the southern California region: a community approach. Prog. Oceanogr. 67, 160-185 (2005).

13. Murphy, G. I. Pattern in life history and the environment. Am. Nat. 102, 391-403 (1968).

14. Hutchings, J. A. \& Reynolds, J. D. Marine fish population collapses: consequences for recovery and extinction risk. BioScience 13, 297-309 (2004).

15. Hutchings, J. \& Baum, J. Measuring marine fishes biodiversity: temporal changes in abundance, life history and demography. Phil. Trans. R. Soc. B 360, 315-338 (2005).

16. Longhurst, A. The sustainability myth. Fish. Res. 81, 107-112 (2006).

17. Hsieh, C. H., Reiss, S. C., Hewitt, R. P. \& Sugihara, G. Spatial analysis shows fishing enhances the climatic sensitivity of marine fishes. Can. J. Fish. Aquat. Sci. (in the press). 
18. Berkeley, S. A., Hixon, M. A., Larson, R. J. \& Love, M. S. Fisheries sustainability via protection of age structure and spatial distribution of fish populations. Fisheries 29, 23-32 (2004).

19. Jonzen, N., Ripa, J. \& Lundberg, P. A theory of stochastic harvesting in stochastic environments. Am. Nat. 159, 427-437 (2002).

20. Dixon, P. A., Milicich, M. J. \& Sugihara, G. Episodic fluctuations in larval supply. Science 283, 1528-1530 (1999).

21. Hsieh, C. H., Glaser, S. M., Lucas, A. J. \& Sugihara, G. Distinguishing random environmental fluctuations from ecological catastrophes for the North Pacific Ocean. Nature 435, 336-340 (2005).

22. Jonzen, N., Lundberg, P., Cardinale, M. \& Arrhenius, F. Variable fishing mortality and the possible commercial extinction of the eastern Baltic cod. Mar. Ecol. Prog. Ser. 210, 291-296 (2001).

23. Jorgensen, C. et al. Managing evolving fish stocks. Science 318, 1247-1248 (2007).

24. Lambert, T. C. Duration and intensity of spawning in herring Clupea harengus as related to the age structure of the population. Mar. Ecol. Prog. Ser. 39, 209-220 (1987).

25. Marteinsdottir, G. \& Steinarsson, A. Maternal influence on the size and viability of Iceland cod (Gadus morhua) eggs and larvae. J. Fish Biol. 52, 1241-1258 (1998).

26. Hutchings, J. A. \& Myers, R. A. Effect of age on the seasonality of maturation and spawning of Atlantic cod, Gadus morhua, in the northwest Atlantic. Can. J. Fish. Aquat. Sci. 50, 2468-2474 (1993)

27. Bobko, S. J. \& Berkeley, S. A. Maturity, ovarian cycle, fecundity, and age-specific parturition of black rockfish (Sebastes melanops). Fish. Bull. 102, 418-429 (2004).

28. Steele, J. H. \& Henderson, E. W. Modeling long-term fluctuations in fish stocks. Science 224, 985-987 (1984).

29. Sugihara, G. Nonlinear forecasting for the classification of natural time series. Phil. Trans. R. Soc. Lond. A 348, 477-495 (1994).

30. Sugihara, G., Grenfell, B. \& May, R. M. Distinguishing error from chaos in ecological time series. Phil. Trans. R. Soc. Lond. B 330, 235-250 (1990).

31. Sugihara, G. et al. Residual delay maps unveil global patterns of atmospheric nonlinearity and produce improved local forecasts. Proc. Natl Acad. Sci. USA 96, 14210-14215 (1999).

32. Hilborn, R. \& Walters, C. J. Quantitative Fisheries Stock Assessment: Choice Dynamics and Uncertainty (Chapman and Hall, New York, 1992).

33. Halley, J. M. Ecology, evolution and 1/f-noise. Trends Ecol. Evol. 11, 33-37 (1996).

34. Steele, J. H. A comparison of terrestrial and marine ecological systems. Nature 313, 355-358 (1985).

35. Vasseur, D. A. \& Yodzis, P. The color of environmental noise. Ecology 85, 1146-1152 (2004).

36. Conover, D. O. \& Munch, S. B. Sustaining fisheries yields over evolutionary time scales. Science 297, 94-96 (2002).

37. Kuparinen, A. \& Merila, J. Detecting and managing fisheries-induced evolution. Trends Ecol. Evol. 22, 652-659 (2007).

38. May, R. M. Biological populations with nonoverlapping generations: stable points, stable cycles, and chaos. Science 186, 645-647 (1974).

39. Hastings, A. \& Powell, T. Chaos in a three-species food chain. Ecology 72 , 869-903 (1991).

40. Ricker, W. E. Changes in the average size and average age of Pacific salmon. Can. J. Fish. Aquat. Sci. 38, 1636-1656 (1981).
41. Harvey, C. J., Tolimieri, N. \& Levin, P. S. Changes in body size, abundance, and energy allocation in rockfish assemblages of the northeast Pacific. Ecol. Appl. 16, 1502-1515 (2006)

42. Armstrong, M., Dann, J. \& Sullivan, K. Programme 1: North East Cod. Fisheries Science Partnership 2006/07 Final Report (Cefas, Lowestoft, 2006).

43. Poulsen, R. T., Cooper, A. B., Holm, P. \& MacKenzie, B. R. An abundance estimate of ling (Molva molva) and cod (Gadus morhua) in the Skagerrak and the northeastern North Sea, 1872. Fish. Res. 87, 196-207 (2007).

44. ICCAT. Standing Committee on Research and Statistics (ICCAT-SCRS) Stock Status Report - Swordfish - North Atlantic 2006 (FAO, Rome, 2006).

45. Murawski, S. A., Rago, P. J. \& Trippel, E. A. Impacts of demographic variation in spawning characteristics on reference points for fishery management. ICES J. Mar. Sci. 58, 1002-1014 (2001).

46. Stefansson, G. \& Rosenberg, A. A. Combining control measures for more effective management of fisheries under uncertainty: quotas, effort limitation and protected areas. Phil. Trans. R. Soc. B 360, 133-146 (2005).

47. Spencer, P. D., Hanselman, D. \& Dorn, M. in Biology, Assessment, and Management of North Pacific Rockfishes. Univ. Alaska Sea Grant Program Report No. AK-SG07-01 (eds Heifetz, J. et al.) 513-533 (Univ. Alaska Fairbanks, Fairbanks, Alaska, 2007).

48. Anonymous. Alaska Groundfish Fisheries Final Programmatic Supplemental Environmental Impact Statement (US Department of Commerce, National Oceanic and Atmospheric Administration, National Marine Fisheries Service, Alaska Region, Juneau, Alaska, 2004).

49. Sibert, J., Hampton, J., Kleiber, P. \& Maunder, M. Biomass, size, and trophic status of top predators in the Pacific Ocean. Science 314, 1773-1776 (2006).

50. Hsieh, C. H., Anderson, C. \& Sugihara, G. Extending nonlinear analysis to short ecological time series. Am. Nat. 171, 71-80 (2008).

Supplementary Information is linked to the online version of the paper at www.nature.com/nature.

Acknowledgements We acknowledge support from National Oceanic and Atmospheric Administration Fisheries and the Environment, the McQuown Chair Endowment in Natural Science, the Deutsche Bank - Jameson Complexity Studies Fund, the Sugihara Family Trust, National Science Council-Long-term Observation Research of the East China Sea, the Center for Marine Bioscience and Biotechnology, and a grant for Biodiversity Research of the 21st Century Center of Excellence at Kyoto University. M. Maunder, P. Hull, V. Dakos, S. Carpenter, J. Bascompte, M. Scheffer, C. Folke, E. H. van Nes, B. Brock, J. Murray, N. Yamamura and $\mathrm{H} .-\mathrm{H}$. Lee provided comments.

Author Contributions G.S., C.N.K.A, C.-h.H., R.M.M. and J.B. helped to frame the original research to investigate hypothesis 3. C.-h.H. and G.S. performed the initial S-map analysis on the CalCOFI data that verified hypothesis 3. C.N.K.A., with assistance from C.-h.H. and G.S., did the model analyses, statistical tests and the documentation of life-history results. All co-authors assisted with the evolution of the research plan and the refinement and final exposition of ideas.

Author Information Reprints and permissions information is available at www.nature.com/reprints. Correspondence and requests for materials should be addressed to G.S. (gsugihara@ucsd.edu). 


\section{Supplementary Figures}

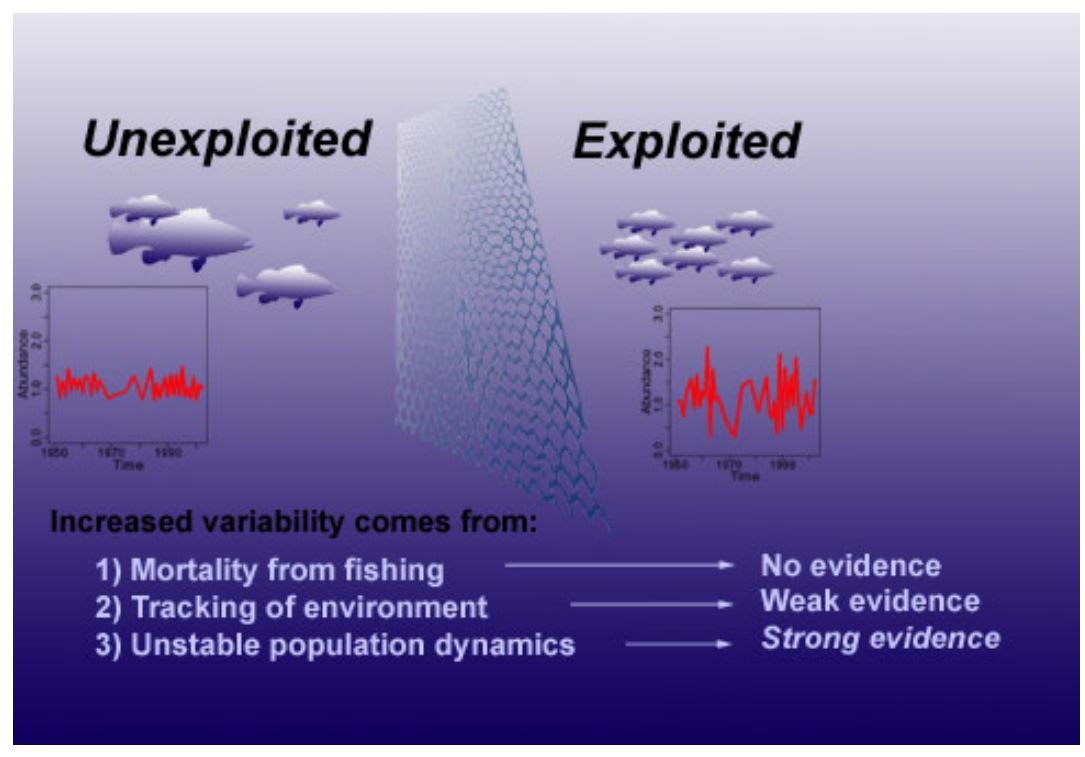

Figure S1 | A schematic figure representing the main findings of this study. 


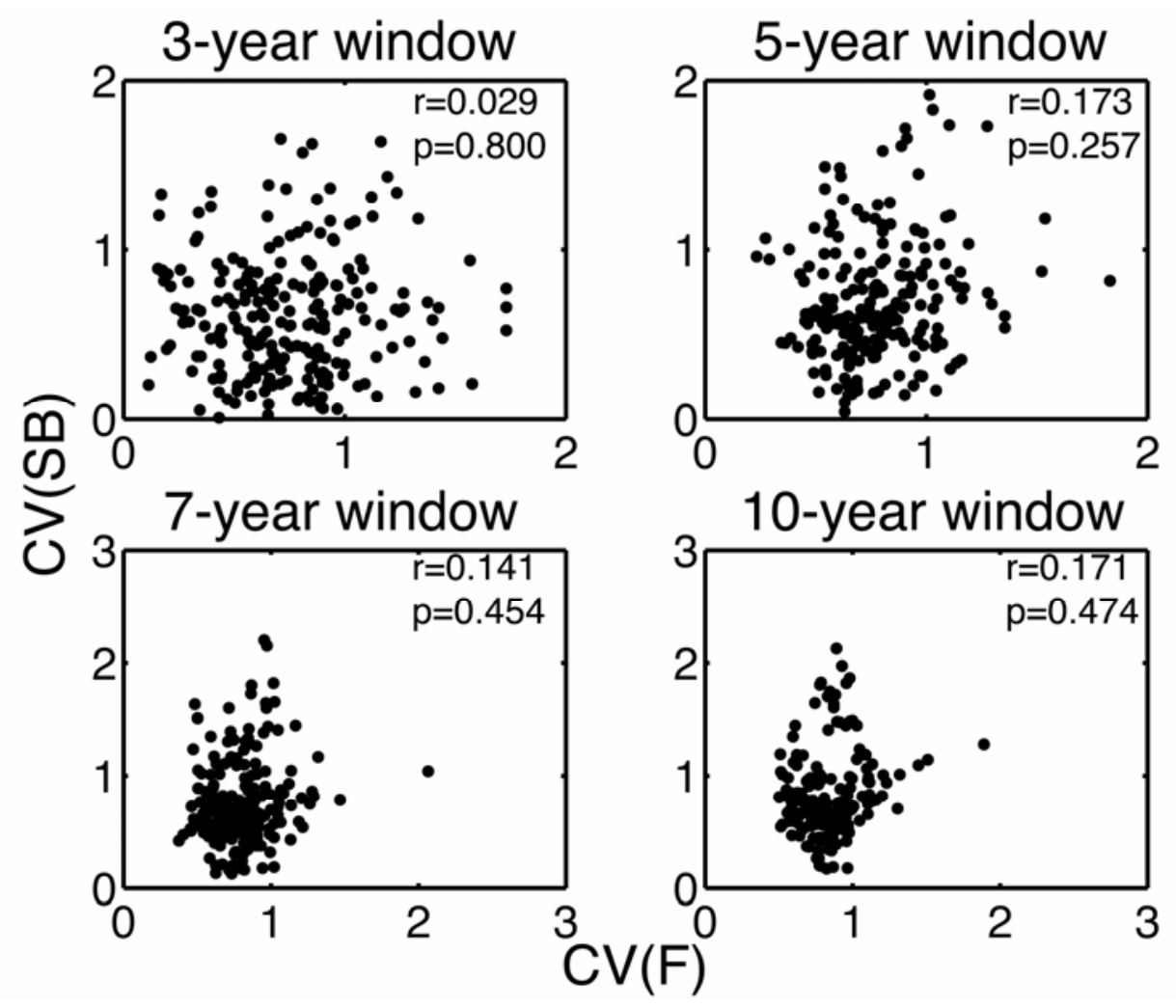

Figure S2 | This figure reproduces Fig. 1, but with spawner biomass (SB) estimated from fishery-dependent data (Table S1). The coefficient of variation in fishing mortality, $\mathrm{CV}(\mathrm{F})$, does not correlate with variability in estimates of spawner biomass, CV(SB), using a 3-, 5-, 7-, and 10-year moving window $\left(r^{2}=0.001,0.030,0.020,0.029 ; P=0.8\right.$, $0.257,0.454,0.474$ respectively). This analysis excludes pacific chub mackerel where policy changes in the allowable catch in response to changes in spawning biomass ${ }^{1}$, introduced an artificial positive relationship. Even including these points, the relationship is marginally significant only at the 5 - and 7 -year scale $\left(r^{2}=0.078,0.123 ; P=0.041\right.$, 0.034). Because there are several ways that fishery-dependent estimates of SB could introduce an artificial relationship between SB and fishing mortality ${ }^{2}$, we view these null results as conservative. 


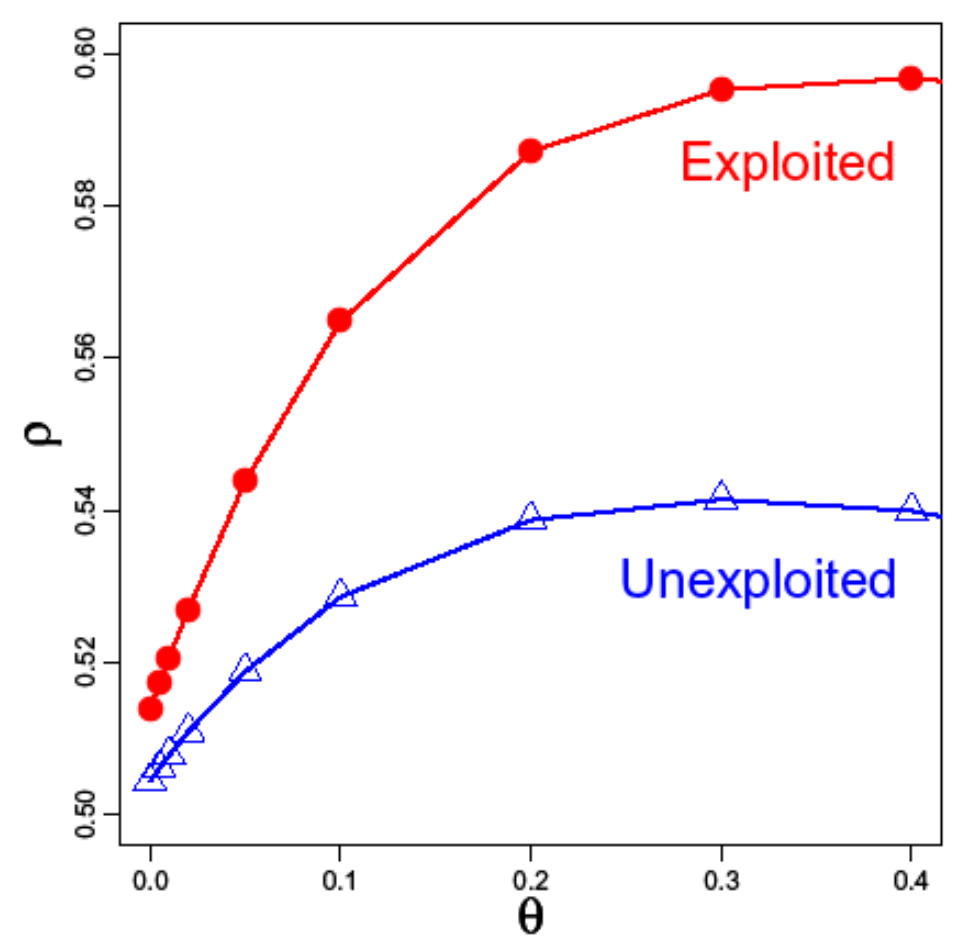

Figure S3 | The difference in predictability $(\rho)$ at the y-intercept (where $\theta=0.0$ ) shows that a linear model makes slightly more accurate forecasts for exploited populations $\left(\rho_{\theta=0}=0.516\right)$ than for unexploited population $\left(\rho_{\theta=0}=0.504\right)$. However, the difference in linear forecast skill is not significant ( $P=0.64$, Fisher's test), which lends only weak support to hypothesis 2 . Furthermore, this slight difference in predictability is dwarfed by the gains in predictability evident when using a nonlinear model $(\theta=0.3)$. Here, the difference between exploited and unexploited populations is much more apparent ( $P=0.003$, Fisher's test), as would be expected under hypothesis 3 . Note the $y$-axis of this figure is the absolute forecast skill $(\rho)$ of each model and not the difference from the linear baseline $(\Delta \rho)$ as presented in Figures 3 and $S 2$. 

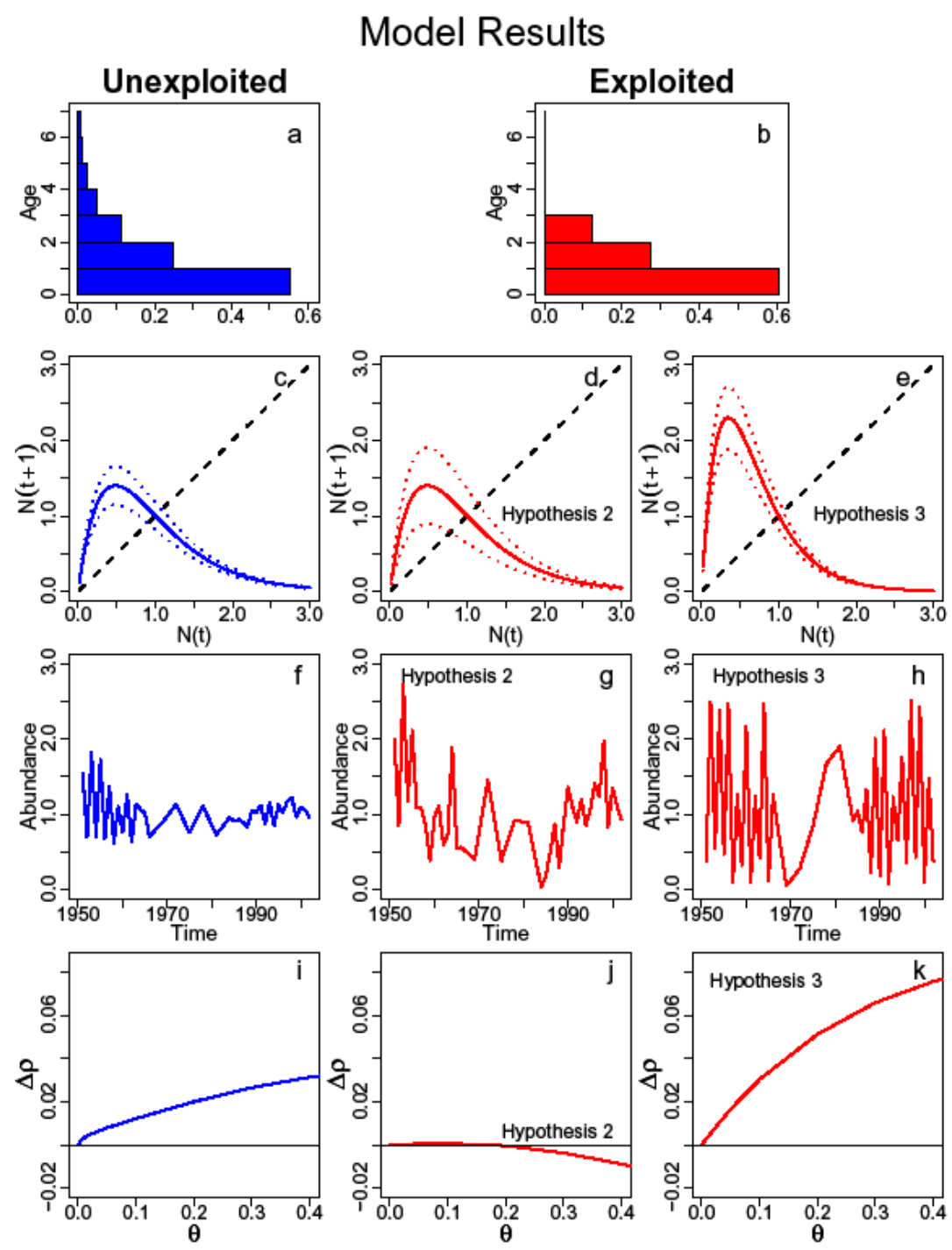

\section{CalCOFI Data}
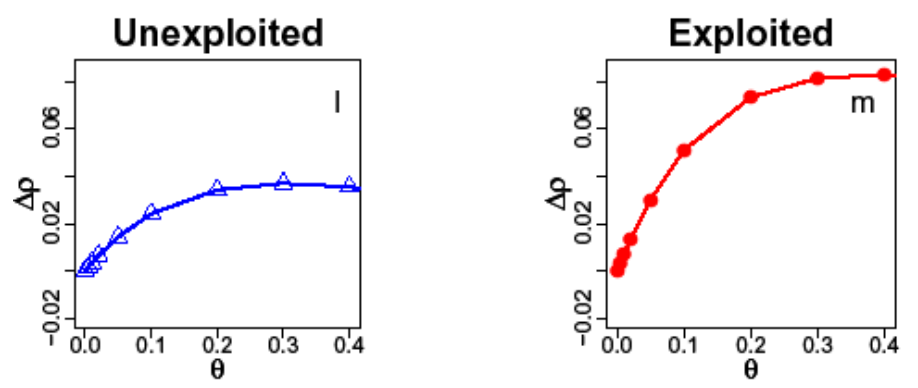
Figure S4 | Model results and observations for unexploited (blue, column 1) and exploited populations (red, columns 2 \& 3). (a) Hypothetical age structure of an unexploited population. (b) Hypothetical age structure of an exploited population showing age truncation. (c) Unexploited species would show a moderate growth rate $r$ and environmental susceptibility $c$ in eqn 1 . (d) The younger population may track the environment more strongly and therefore deviate further from the growth function (hypothesis 2 modelled by increasing $c$ ), or (e) the young population may change demographic parameters (hypothesis 3 modelled by increasing $r$ ). Example time series of species under (f) unexploited conditions or ( $(\mathbf{g}-\mathbf{h})$ two models of exploitation. Either mechanism results in a population that fluctuates more dramatically through time. Smaps of species modelled under three regimes: (i) unexploited, showing moderate nonlinearity (a positive $\Delta \rho$ at $\theta>0$, with a larger $\Delta \rho$ indicating more nonlinearity $\left(\Delta \rho=\rho_{\theta>0}\right.$ $\left.-\rho_{\theta=0}\right)$; (j) exploited under hypothesis 2 , showing less or no nonlinearity; (k) and exploited under hypothesis 3, showing more nonlinearity. (I-m) Analysis of CalCOFI ichthyoplankton data show that fished species show more nonlinearity than unfished species. 

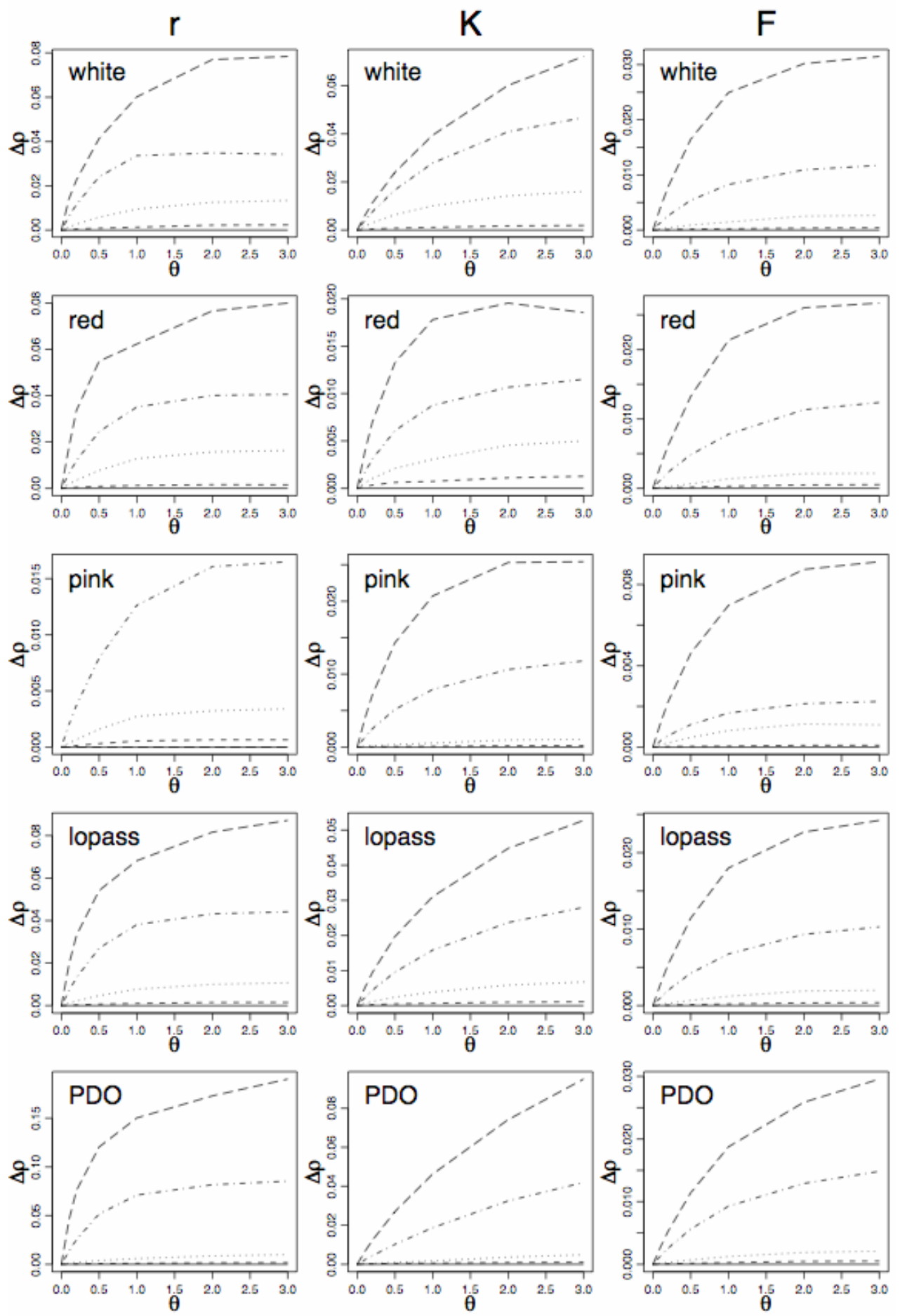
Figure S5 | Allowing demographic parameters $r$ or $K$ to vary though time (where $N_{t+1}=$ $N_{t} e^{r_{t}\left(1-N_{\ell} / K_{J}\right)}$, see methods) causes the time series to appear more nonlinear, regardless of the correlation structure of the variance. The larger the $\mathrm{CV}$, the more nonlinear the time series signature (standard deviations for each line are solid $=0$, shortdash $=0.05$, dotted $=0.1$, dash-dot $=0.2$, longdash $=0.3$ ). Similar results were obtained when fishing mortality $\left(F_{t}\right)$ was given mean 0.3 and allowed to vary in $N_{t+1}=N_{t} e^{r_{t}\left(1-N_{t} / K_{t}-F_{t}\right)}$ while $r_{t}$ and $K_{t}$ were held fixed (see Methods). 


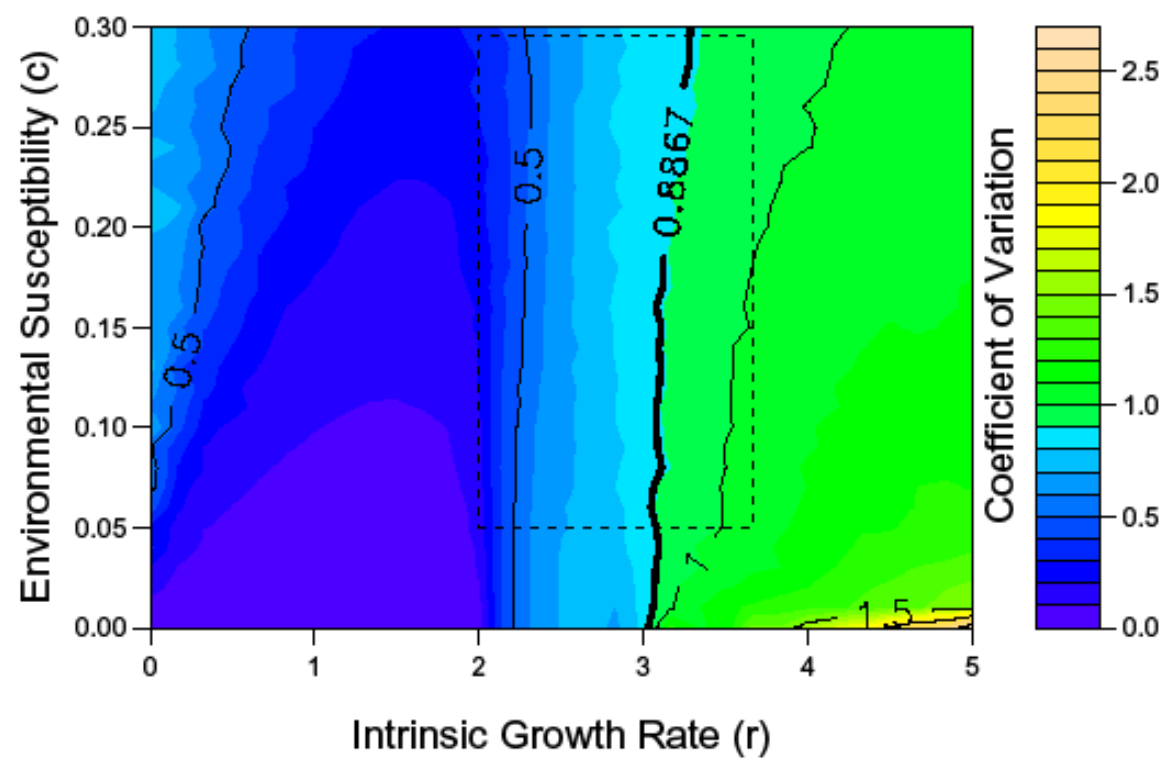

Figure S6 | The coefficient of variation for a 40-point time series governed by (1) was approximated by 96,100 time series with values of $r$ in the range $[0,5]$ and $c$ in the range $[0.00,0.30]$. The tangent to the CV surface at 0.8667 (the observed CV of unexploited CalCOFI species) was approximated for the area delimited by the dashed box. The parameter $c$ was dropped from the tangent fit, because $r$ alone was able to explain more than $90 \%$ of the variation in $\mathrm{CV}$ in this region. 


\section{Supplementary Tables}

Table S1. Data sources for the spawning biomasses and fishing mortality from stock assessment reports for seven exploited species.

\begin{tabular}{llll}
\hline Species & Common name & $\begin{array}{l}\text { Domain of } \\
\text { assessment }\end{array}$ & Source \\
\hline Engraulis mordax & Northern anchovy & California & 3 \\
Merluccius productus & Pacific hake & US west coast & 4 \\
Sardinops sagax & Pacific sardine & California & 5,6 \\
Scomber japonicus & Pacific chub mackerel & US west coast & 7 \\
Microstomus pacificus & Dover sole & US west coast & 8 \\
Scorpaenichthys marmoratus & Cabezon & Southern California & 9 \\
Sebastes paucispinis & Bocaccio & California & 10 \\
\hline
\end{tabular}

Table S2. The percent of variation $\left(\mathrm{r}^{2}\right)$ in larval abundance explained by major environmental indices for CCE species. No environmental variable explained more than $1.5 \%$, and no correlations were significant when Bonferroni corrected $(*=P<0.05)$. (See also Hsieh et al. ${ }^{11}$ for analyses on each individual species).

\begin{tabular}{lllll}
\hline $\begin{array}{l}\text { Physical time } \\
\text { series }\end{array}$ & \multicolumn{2}{l}{ Exploited species } & Unexploited species \\
\hline & $\begin{array}{l}\text { Abundance } \\
(\mathbf{n = 5 2 0})\end{array}$ & $\begin{array}{l}\boldsymbol{\Delta} \text { Abundance } \\
(\mathbf{n}=\mathbf{5 0 7})\end{array}$ & $\begin{array}{l}\text { Abundance } \\
(\mathbf{n}=\mathbf{6 4 0})\end{array}$ & $\begin{array}{l}\boldsymbol{\Delta} \text { Abundance } \\
(\mathbf{n}=\mathbf{6 2 4})\end{array}$ \\
\hline La Jolla SST & $0.0086^{*}$ & 0.0000 & 0.0022 & 0.0008 \\
$\Delta$ SST & $0.0134^{*}$ & $0.0085^{*}$ & 0.0039 & 0.0011 \\
La Jolla Salinity & 0.0028 & 0.0000 & 0.0002 & 0.0005 \\
$\Delta$ Salinity & 0.0022 & 0.0013 & 0.0035 & 0.0052 \\
Annual PDO & 0.0002 & 0.0009 & 0.0000 & 0.0010 \\
$\Delta$ PDO & 0.0002 & 0.0002 & 0.0021 & 0.0002 \\
Annual NPI & 0.0005 & $0.0137^{*}$ & 0.0015 & $0.0087^{*}$ \\
$\Delta$ NPI & 0.0038 & 0.0042 & 0.0026 & 0.0011 \\
Annual SOI & 0.0000 & 0.0003 & 0.0002 & 0.0007 \\
$\Delta$ SOI & 0.0007 & 0.0021 & 0.0013 & 0.0001 \\
\hline
\end{tabular}


Table S3. The correlation coefficient $(\rho)$ between the $C V(\Delta$ Larval density) and

$\mathrm{CV}(\Delta$ Environmental Index $)$ over a 5-year moving window. No significant correlations were obtained for any single species $(\mathrm{n}=33$ overlapping windows; critical values of $|\rho|: 0.70$ [P=0.05], $0.83[\mathrm{P}=0.01]$, and $0.92[\mathrm{P}=0.001])$. No significant results were obtained with window sizes of 3 , 7 , or 10 years either.

\begin{tabular}{|c|c|c|c|c|c|}
\hline & SST & NPI & PDO & SOI & BUI \\
\hline $\begin{array}{l}\text { All Exploited Species } \\
\rho(P)\end{array}$ & $\begin{array}{l}0.01 \\
(0.94)\end{array}$ & $\begin{array}{l}-0.05 \\
(0.706)\end{array}$ & $\begin{array}{l}-0.18 \\
(0.139)\end{array}$ & $\begin{array}{l}-0.2 \\
(0.11)\end{array}$ & $\begin{array}{l}0.1 \\
(0.423)\end{array}$ \\
\hline Engraulis mordax & -0.02 & 0.03 & 0.08 & 0.06 & 0.18 \\
\hline Merluccius productus & 0.20 & -0.59 & 0.11 & 0.01 & 0.32 \\
\hline Microstomus pacificus & 0.23 & 0.03 & -0.20 & -0.23 & 0.17 \\
\hline Paralabrax spp. & 0.10 & -0.15 & 0.12 & -0.10 & -0.06 \\
\hline Paralichthys californicus & -0.51 & 0.35 & -0.32 & -0.38 & 0.00 \\
\hline Parophrys vetulus & 0.38 & -0.63 & -0.08 & -0.40 & 0.31 \\
\hline Sardinops sagax & -0.21 & -0.19 & 0.04 & 0.00 & 0.05 \\
\hline Scomber japonicus & 0.06 & 0.26 & -0.36 & -0.36 & -0.09 \\
\hline Scorpaenichthys marmoratus & -0.11 & -0.11 & -0.08 & -0.39 & -0.16 \\
\hline Sebastes aurora & 0.01 & 0.08 & -0.60 & -0.62 & 0.21 \\
\hline Sebastes paucispinis & -0.01 & -0.02 & -0.48 & -0.27 & 0.02 \\
\hline Sphyraena argentea & -0.30 & -0.15 & -0.27 & 0.08 & 0.31 \\
\hline Trachurus symmetricus & 0.04 & 0.28 & -0.38 & -0.23 & 0.02 \\
\hline $\begin{array}{l}\text { All Unexploited Species } \\
\rho(P)\end{array}$ & $\begin{array}{l}-0.02 \\
(0.836)\end{array}$ & $\begin{array}{l}0.03 \\
(0.769)\end{array}$ & $\begin{array}{l}0.06 \\
(0.602)\end{array}$ & $\begin{array}{l}0.01 \\
(0.964)\end{array}$ & $\begin{array}{l}-0.01 \\
(0.908)\end{array}$ \\
\hline Argentina sialis & -0.21 & 0.32 & -0.08 & 0.34 & -0.08 \\
\hline Chromis punctipinnis & 0.20 & -0.08 & 0.35 & 0.05 & -0.17 \\
\hline Cololabis saira & 0.53 & -0.39 & 0.58 & 0.35 & -0.10 \\
\hline Hippoglossina stomata & 0.35 & -0.09 & 0.00 & 0.09 & -0.39 \\
\hline Hypsoblennius spp. & -0.29 & 0.26 & 0.00 & -0.13 & -0.14 \\
\hline Icichthys lockingtoni & -0.39 & 0.23 & -0.01 & -0.05 & 0.23 \\
\hline Leuroglossus stilbius & 0.29 & -0.16 & 0.35 & 0.32 & -0.02 \\
\hline Lyopsetta exilis & -0.23 & 0.17 & 0.07 & 0.26 & -0.04 \\
\hline Ophidion scrippsae & 0.13 & -0.09 & -0.06 & -0.29 & -0.09 \\
\hline Oxylebius pictus & -0.46 & 0.37 & -0.07 & -0.24 & 0.32 \\
\hline Pleuronichthys verticalis & 0.17 & 0.29 & 0.56 & 0.39 & -0.39 \\
\hline Sebastes jordani & -0.16 & 0.15 & -0.29 & -0.43 & 0.45 \\
\hline Symphurus atricaudus & 0.00 & -0.54 & 0.21 & -0.05 & 0.17 \\
\hline Tetragonurus cuvieri & -0.21 & 0.01 & 0.10 & -0.07 & 0.17 \\
\hline Trachipterus altivelis & -0.04 & -0.12 & -0.39 & -0.28 & -0.02 \\
\hline Zaniolepis spp. & -0.31 & 0.67 & -0.45 & 0.06 & -0.15 \\
\hline
\end{tabular}


Table S4. Life history data for the CalCOFI fishes ${ }^{13}$. Missing data (bold) are imputed based on their correlation structure ${ }^{13}$, using Expectation-Maximization algorithm assuming multivariate normal distribution ${ }^{14}$. Many of these life history traits are related (as discussed in Hsieh et. al. 2006). The growth rate from von Bertalanffy's growth function (VBGF) is derived from prior data using the relationship

$L(t)=L_{\infty}\left(1-e^{-k t}\right) \rightarrow k=-\left[\ln \left(1-\left(L(t) / L_{\infty}\right)\right) / t\right]=-[(\ln (1-(\operatorname{SSM} / \operatorname{MaxSz})) / A S M]$

\begin{tabular}{|c|c|c|c|c|c|c|c|c|c|}
\hline Species & $\begin{array}{l}\text { Max } \\
\text { size } \\
\mathrm{L}_{\infty}\end{array}$ & $\begin{array}{l}\text { Size at } \\
\text { maturity } \\
\text { (cm) }\end{array}$ & $\begin{array}{l}\text { Age at } \\
\text { maturity } \\
\text { (year) }\end{array}$ & $\begin{array}{l}\text { Fecundity } \\
\text { (Eggs per } \\
\text { year) }\end{array}$ & $\begin{array}{l}\text { Spawn } \\
\text { duration } \\
\text { (months) }\end{array}$ & $\begin{array}{l}\text { Trophic } \\
\text { level }\end{array}$ & Fished & $\begin{array}{l}\text { Coefficient } \\
\text { of } \\
\text { Variation }\end{array}$ & $\begin{array}{l}\text { VBGF } k \\
\text { (per yr) }\end{array}$ \\
\hline Argentina sialis & 22 & 12 & 2 & 11271 & 11 & 3.1 & no & 0.986 & 0.39 \\
\hline Chromis punctipinnis & 30 & 15 & 2 & 28854 & 4 & 2.73 & no & 1.092 & 0.35 \\
\hline Cololabis saira & 40 & 27 & 1.5 & 215000 & 11 & 3.71 & no & 0.895 & 0.75 \\
\hline Engraulis mordax & 24.8 & 9 & 1 & 150000 & 12 & 3.1 & yes & 0.936 & 0.45 \\
\hline $\begin{array}{l}\text { Hippoglossina } \\
\text { stomata }\end{array}$ & 40 & 16.2 & 3 & 68872 & 8 & 3.23 & no & 0.695 & 0.17 \\
\hline Hypsoblennius jenkins & 13 & 4.6 & 1 & 900 & 7 & 2.24 & no & 1.168 & 0.44 \\
\hline Icichthys lockingtoni & 46 & 21 & 2.5 & 105873 & 7 & 3.6 & no & 0.690 & 0.24 \\
\hline Leuroglossus stilbius & 15 & 8 & 2.5 & 3533 & 6 & 3.24 & no & 0.646 & 0.3 \\
\hline Lyopsetta exilis & 35 & 17 & 3 & 46166 & 6 & 3.44 & no & 0.747 & 0.22 \\
\hline Merluccius productus & 91 & 40 & 3.5 & 2500000 & 4 & 3.83 & yes & 1.416 & 0.17 \\
\hline Microstomus pacificus & 76 & 33.2 & 5.5 & 83000 & 6 & 3.36 & yes & 0.921 & 0.1 \\
\hline Ophidion scrippsae & 28 & 16 & 1 & 23389 & 6 & 3.5 & no & 1.134 & 0.85 \\
\hline Oxylebius pictus & 25 & 14 & 3 & 1780 & 9 & 3.42 & no & 0.766 & 0.27 \\
\hline Paralabrax clathratus & 72 & 23 & 3 & 81000 & 5 & 3.98 & yes & 1.672 & 0.13 \\
\hline $\begin{array}{l}\text { Paralichthys } \\
\text { californicus }\end{array}$ & 152 & 41 & 4.5 & 2200000 & 12 & 4.5 & yes & 1.144 & 0.07 \\
\hline Parophrys vetulus & 57 & 23 & 4 & 1500000 & 6 & 3.45 & yes & 0.874 & 0.13 \\
\hline $\begin{array}{l}\text { Pleuronichthys } \\
\text { verticalis }\end{array}$ & 37 & 17 & 4 & 54721 & 11 & 3.17 & no & 0.807 & 0.15 \\
\hline Sardinops sagax & 39.5 & 15.8 & 2 & 1300000 & 8 & 2.59 & yes & 1.891 & 0.26 \\
\hline Scomber japonicus & 60 & 32 & 2 & 1120000 & 7 & 3.35 & yes & 2.211 & 0.38 \\
\hline $\begin{array}{l}\text { Scorpaenichthys } \\
\text { marmoratus }\end{array}$ & 99 & 50 & 4.5 & 152000 & 7 & 3.51 & yes & 0.728 & 0.16 \\
\hline Sebastes aurora & 41 & 28 & 5 & 74608 & 7 & 3.26 & yes & 0.673 & 0.23 \\
\hline Sebastes jordani & 31 & 14 & 3 & 50000 & 4 & 3.22 & no & 0.739 & 0.2 \\
\hline Sebastes paucispinis & 91 & 36 & 4 & 1160000 & 5 & 3.51 & yes & 0.834 & 0.13 \\
\hline Sphyraena argentea & 122 & 56 & 2 & 225000 & 6 & 4.5 & yes & 1.378 & 0.31 \\
\hline Symphurus atricaudus & 21 & 11 & 1 & 9799 & 5 & 3.3 & no & 1.804 & 0.74 \\
\hline Tetragonurus cuvieri & 70 & 30 & 3 & 377000 & 12 & 3.78 & no & 0.823 & 0.19 \\
\hline Trachipterus altivelis & 183 & 63 & 4 & 6920510 & 12 & 3.9 & no & 0.473 & 0.11 \\
\hline $\begin{array}{l}\text { Trachurus } \\
\text { symmetricus }\end{array}$ & 81 & 31 & 3 & 1856000 & 6 & 3.86 & yes & 0.930 & 0.16 \\
\hline Zaniolepis frenata & 25 & 13 & 2.5 & 16647 & 9 & 3.44 & no & 0.721 & 0.29 \\
\hline
\end{tabular}




\section{Supplementary Discussion}

Comment on Generality of Results to Fisheries Models: Results in Fig. S4 (that show an increase in population variability and nonlinearity with increased growth rates) are generic to compensatory discrete-time fisheries population models where the growth curve steepens about $N_{t}=N_{t+1}$ (equilibrium) as growth rate increases (e.g., Schaefer, Pella-Tomlinson, or DerisoSchnute difference models ${ }^{12}$ ). We note that Beverton-Holt ${ }^{12}$ type spawner - recruitment models only address new production and are not intended to account for possible density dependent mortality dynamics after recruitment ${ }^{13}$. As such, they are not intended to be complete population Comment [p1]: Add models and they do not apply to this study where the focus is on year-to-year variation of total spawner biomass. Recall that ichthyoplankton surveys are indicators of current spawning stock biomass, and do not represent recruitment ${ }^{11,14}$. These results would not hold for models without density-dependence (e.g. exponential growth, constant mortality). 


\section{Supplementary Notes}

Leet, W. S., Dewees, C. M., Klingbeil, R., \& Larson, E. J. eds. California's living marine resources: A status report. (California Department of Fish and Game, Oakland, 2001). Lesueur, M., Gascuel, D., \& Rouyer, T. Control of assessment for demersal fish stocks in ICES area: analysis for 36 stocks and investigation of some potential bias sources. ICES CM K, 17 (2004).

Jacobson, L. D., Lo, N. C. H., \& Barnes, J. T. A biomass-based assessment model for northern anchovy, Engraulis mordax. Fish. Bull. U. S. 92, 711-124 (1994).

Helser, T. E., Methot, R. D., \& Fleischer, G. W. Stock assessment of Pacific hake (whiting) in U.S. and Canadian waters in 2003. (Pacific Fishery Management Council, 2003).

MacCall, A. D. Population estimate for the waning years of the Pacific sardine fishery. CalCOFI Rep. 20, 72-82 (1979).

Conser, R. et al. Assessment of the Pacific sardine stock for U.S. management in 2005. (Pacific Fishery Management Council, 2004).

Hill, K. T. \& Crone, P. R. Assessment of the Pacific mackerel (Scomber japonicus) stock for U.S. management in the 2005-2006 season. (Pacific Fishery Management Council, 2005).

Sampson, D. B. The status of Dover sole off the U.S. West coast in 2005. (Pacific Fishery Management Council, 2005).

Cope, M. J. \& Punt, A. E. Status of cabezon (Scorpaenichthys marmoratus) in California waters as assessed in 2005. (Pacific Fishery Management Council, 2005).

MacCall, A. D. Status of bocaccio off California in 2003. (Pacific Fishery Management Council, 2003).

Hsieh, C. H. et al. A comparison of long-term trends and variability in populations of larvae of exploited and unexploited fishes in the Southern California region: A community approach. Prog. Oceanogr. 67, 160-185 (2005).

Hilborn, R. \& Walters, C. J. Quantitative fisheries stock assessment: choice, dynamics \& uncertainty. (Chapman and Hall, New York, 1992).

Rose, K. A. et al. Compensatory density dependence in fish populations: importance, controversy, understanding and prognosis. Fish and Fisheries 2, 293-327 (2001).

Hsieh, C. H. et al. Fishing elevates variability in the abundance of exploited species. Nature 443, 859-862 (2006). 
messenger RNA. Isalan et al. recombined the promoters and ORFs of unrelated genes, encoding many of the 300 transcription factors in the E. coli genome, to create about 600 new promoter-ORF connections, or genes. They then placed each of these genes, one at a time, into E. coli cells and measured their viability.

This type of genetic rewiring is akin to randomly placing wires between nodes within a computer's central processing unit, where the new wires would reroute signals from one section of the processor to another - perhaps unrelated - section. The introduction of new network connections will almost certainly preclude a central processing unit from operating properly, if at all. Surprisingly, Isalan and colleagues ${ }^{3}$ find that the genetic network of $E$. coli is much more robust to rewiring than its electronic counterpart. Of the roughly 600 new connections the authors introduced into the network, almost all were well tolerated by the cells. Furthermore, the vast majority of connections showed no apparent deleterious effects, and some strains even grew better than the original.

These observations indicate that small-scale rewiring events probe the network landscape for fitness of the associated changes, without causing great detriment to the organism. From an evolutionary standpoint, therefore, they indicate that organisms can evolve by changing the architecture of their genetic network. This certainly makes sense, otherwise new network functionality could evolve only by large-scale rewiring events, which are probably extremely rare.

This conclusion also flies in the face of the popular misconception among opponents of the evolutionary theory, who believe that the genetic code is irreducibly complex. For instance, advocates of 'intelligent design' compare the genome to modern engineered machines such as integrated circuits and clocks, which will cease to function if their internal design is altered. Although sometimes it is instructive to point to similarities between the design principles behind modern technology and those behind genetics, the analogy can only go so far. Engineered devices are generally designed to work just above the point of failure, so that any tampering with their construction will result in catastrophe. In the event of failure, new clocks can be purchased or central processing units replaced. But nature does not have that option. To survive - and so evolve — organisms must be able to tolerate random mutations, deletions and recombination events. And Isalan and colleagues' work provides an important step forward in quantifying just how robust the genetic code can be.

In addition to screening the new strains for fitness, the authors measured the activity levels of genes that were most directly affected by network rewiring. They predicted that, if a new gene introduces a feedback loop into the network, the protein levels of its 'parent' gene should be altered accordingly. For instance, the synthetic gene inserted into the simple generegulatory network depicted in Figure 1 introduces a positive feedback loop into the creation of the protein encoded by $\mathrm{ORF}_{1}$. Therefore, levels of that protein should be higher in the mutant than in the normal strain. But this is not what Isalan et al. find. Instead, introduction of direct feedback loops (either positive or negative) led to no significant differences in the levels of the proteins concerned.

There could be two explanations for why new feedback loops have almost no effect on protein levels. For one, the dynamics of largescale, transcriptionally regulated genetic networks are probably more complicated than thought. In other words, analysing large networks by decomposing them into simpler subnetworks, as Isalan et al. have done, may lead to faulty conclusions about how the subsystems work within the whole. Alternatively, it may be that transcriptional regulation is less important than expected. Perhaps post-transcriptional regulatory mechanisms ${ }^{4,5}$ that affect mRNA translation regulate the network to a larger extent. But considerable effort has gone into the creation of synthetic gene networks $s^{6,7}$ that are controlled at the transcriptional level, and many of these studies have had great success ${ }^{8,9}$. So the findings of Isalan et al. ${ }^{3}$ should be seen both as a cautionary tale and as encouragement for research into the regulatory mechanisms of large-scale networks.

Matthew R. Bennett and Jeff Hasty are in the Department of Bioengineering and Institute for Nonlinear Science, University of California, San Diego, La Jolla, California 92093-0412, USA.

e-mail: hasty@bioeng.ucsd.edu

1. Baba, T. et al. Mol. Syst. Biol. doi:10.1038/msb4100050 (2006).

2. Sopko, R. et al. Mol. Cell 21, 319-330 (2006).

3. Isalan, M. et al. Nature 452, 840-845 (2008).

4. Filipowicz, W., Bhattacharyya, S. N. \& Sonenberg, N. Nature Rev. Genet. 9, 102-114 (2008).

5. Isaacs, F. J., Dwyer, D. J. \& Collins, J. J. Nature Biotechnol. 24, 545-554 (2006)

6. Wall, M. E., Hlavacek, W. S. \& Savageau, M. A. Nature Rev. Genet. 5, 34-42 (2004).

7. Hasty, J., Isaacs, F., Dolnik, M., McMillen, D. \& Collins, J. J. Chaos 11, 207-220 (2001).

8. McDaniel, R. \& Weiss, R. Curr. Opin. Biotechnol. 16, 476-483 (2005)

9. Elowitz, M. B. \& Leibler, S. Nature 403, 335-338 (2000).

\section{ECOLOGY \\ Destabilized fish stocks \\ Nils Chr. Stenseth and Tristan Rouyer \\ Fishing of natural populations increases the variability of fish abundance. A unique data set from the southern California Current has allowed an evaluation of three hypotheses for why that should be so.}

Understanding variation in the abundances of plants and animals has long been a central topic in population ecology ${ }^{1}$. It is one of particular significance when it comes to exploited populations, such as those of many fish stocks, and is revisited by Anderson et al. on page 835 of this issue ${ }^{2}$.

Extensive fluctuations of harvested fish stocks are clearly undesirable economically - too much uncertainty in expected income will adversely affect fishing communities. Such fluctuations are also harmful from a conservation perspective, as high variability may increase the (local) probability of extinctions. It has long been suggested ${ }^{3}$ by fisheries ecologists that fishing might itself increase the temporal variability of exploited populations. But long-term data on unexploited populations are needed for comparative (control) purposes, and the lack of such data has made it difficult to separate the effects of fishing from the effects of variations in environmental conditions.

In 2006, such a long-term data set - the California Cooperative Oceanic Fisheries Investigations (CalCOFI) record of larval fish abundance - was subject to comparative analysis by Hsieh et al. ${ }^{4}$, from which they concluded that, as their title put it, 'Fishing elevates variability in the abundance of exploited species. But this study, pioneering as it was, did not look into the nature of the underlying mechanisms. Anderson et al. ${ }^{2}$, a group that includes many of the same authors, now report an extended analysis of the 50-year CalCOFI data set under the title 'Why fishing magnifies fluctuations in fish abundance'. In doing so they provide valuable, empirically based insights into the fluctuations of exploited populations. Their analysis convincingly shows that the observed increased variation of harvested fish stocks is caused by the selective removal of the larger (and older) individuals, leading to a decreasing average size and age of the fish that destabilizes the population dynamics.

Anderson et al. ${ }^{2}$ looked at three hypotheses. They found no support for the first one, that the observed variability of exploited fish stocks is a direct effect of variable fishing intensity. Then there is the selective removal of larger and so older individuals by fishing, known as the age-truncation effect. This 'juvenescence' of the population can affect the dynamics in two ways, leading to the second and third hypotheses.

The second hypothesis is that younger, smaller individuals may be more susceptible 


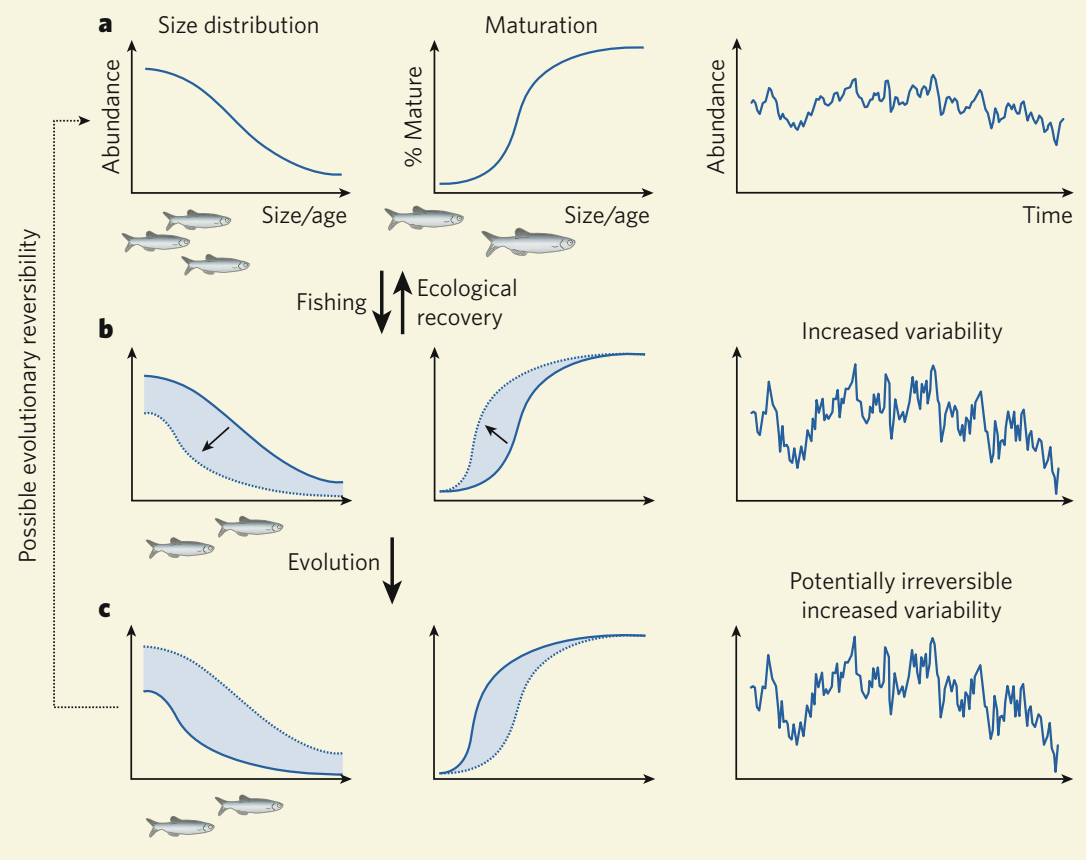

Figure 1 | The ecological and evolutionary effects of fishing on fish-stock dynamics ${ }^{2}$. a, The size distribution and maturation profile of an unexploited population, which shows a certain level of variability in abundance over time. $b$, The age-truncation - juvenescence - effect caused by fishing leads to a population with a lower average age, and is often associated with individuals attaining maturity at younger ages. The result is increased variability in abundance. If the change is phenotypic (ecological) only, recovery is possible. c, A more permanent (evolutionary) change in the demographics leads to potentially irreversible increased variability in abundance, unless there is a high degree of genetic variability left in the population to return it to the unexploited state.

to environmental change than older, larger individuals that, as the authors put it, can survive hard times better. The third is that the changed age structure may affect demographic parameters, such as the age of maturation, and intensify the nonlinear nature of the processes involved in population dynamics (for example, through an increased population growth rate, or by increasing the nonlinear coupling of demographic parameters to environmental changes). Anderson and co-workers find some support for the former effect and strong support for the latter - that is, the observed increase in population variability seems to be caused by an increased nonlinearity of the underlying population dynamics of exploited fish stocks as compared with unexploited populations.

The higher mortality experienced by older and bigger fish, directly caused by size-selective harvesting, can induce earlier maturation of fish within the stock, and can do so in two ways that are not mutually exclusive. One is 'phenotypic plasticity', the ability of the fish to change its characteristics, or phenotype, in response to changes in its environment. This is a reversible response that is primarily an ecological effect ${ }^{5}$. The other is a potentially irreversible evolutionary response due to harvesting $^{5-8}$. Many recent studies have provided evidence for this second effect, and show that the ecological-evolutionary consequences of harvesting can occur at a much faster rate than previously thought. Through the evolutionary effect, for which there is growing support $^{7,9}$, age truncation can make the abundance of exploited fish stocks permanently more variable (Fig. 1).

Taken together with Anderson and colleagues' findings ${ }^{2}$, the implication is that fisheries management needs to give priority to precautionary measures. Juvenescence may be irreversible ${ }^{9}$. When the ecological effects of fishing a particular population are observed, the evolutionary consequences may have already set in, and may be irreversible, or

\section{ASTROPHYSICS}

\section{Dieter Breitschwerdt}

It has long been known that 'starburst' galaxies, which have extremely high rates of star formation, extravagantly blow away some of their star-forming gas. Writing in The Astrophysical Journal, Everett et al. ${ }^{1}$ produce convincing evidence that, although it forms stars at a more moderate rate, our own Milky Way also belongs to this profligate club. In a new twist, it seems that the high-energy particles known as at least only slowly reversible, depending on whether sufficient genetic variability remains in the stocks ${ }^{10}$. In other words, it will often be quicker to create a demographic change in a fish stock than to reverse that change and the increased variability in population abundance that stems from it.

The combined ecological and evolutionary juvenescence of exploited populations prompts various thoughts. Ecologists need to give more consideration to the ecological effects of lifehistory changes such as earlier maturation, and evolutionary biologists need to take more account of the ecological effects of evolutionary changes. Indeed, we would like to see many more combined ecological and evolutionary studies on the effect of exploitation. Such a research agenda is not easy to implement, given the scarcity of long-term data on unexploited fish stocks, and we require more data sets like the CalCOFI record. Otherwise, investigation of the heritability of the demographic parameters that Anderson et al. conclude amplify the nonlinear population behaviour would help us understand the evolutionary effect of the observed changes - and also help in assessing to what degree such an effect could be reversed through management policies.

Nils Chr. Stenseth and Tristan Rouyer are at the

Centre for Ecological and Evolutionary Synthesis, Department of Biology, University of Oslo, PO Box 1066 Blindern, N-0316 Oslo, Norway. e-mail:n.c.stenseth@bio.uio.no

1. May, R. Theoretical Ecology: Principles and Applications (Blackwell, Oxford, 1976).

2. Anderson, C. N. K. et al. Nature 452, 835-839 (2008).

3. Beddington, J. R. \& May, R. M. Science 197, 463-465 (1977).

4. Hsieh, C. et al. Nature 443, 859-862 (2006).

5. Ernande, B., Dieckmann, U. \& Heino, M. Proc. R. Soc. Lond. B 271, 415-423 (2003).

6. Olsen, E. M. et al. Nature 428, 932-935 (2004).

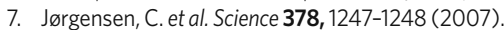

8. Hilborn, R. Fisheries 31, 554-555 (2006).

9. Law, R. \& Grey, D. R. Evol. Ecol. 3, 343-359 (1989).

10. Futuyma, D. J. Evolutionary Biology 3rd edn (Sinauer Sunderland, MA, 1998).

\section{Blown away by cosmic rays}

\section{X-ray data reveal that our Galaxy is shedding part of its gas, a phenomenon previously associated only with much more active star-forming galaxies. So what is driving the process in the Milky Way?}

cosmic rays are among the agents of the Milky Way's wind.

That galaxies should so casually discard some of their substance might seem surprising, for the process by which they come into being is long and arduous. Galaxies began to be assembled from primordial gas pulled together by the gravity of mysterious, unseen 'dark matter' during the infancy of our Universe, 